\title{
DESAIN MEDIA PEMBELAJARAN FISIKA MENGGUNAKAN SOFTWARE PREZI BERBASIS SCIENTIFIC MATERI TATA SURYA KELAS VIII
}

\author{
Dini Maryuning Tias ${ }^{1)}$, Astalini $^{2)}$, dan Haerul Pathoni ${ }^{3)}$ \\ ${ }^{1)}$ Mahasiswa S1 Program Studi Pendidikan Fisika FKIP Universitas Jambi, Jambi, Indonesia \\ ${ }^{2) 33}$ Dosen Program Studi Pendidikan Fisika FKIP Universitas Jambi, Jambi, Jambi, Indonesia \\ Email: dini.maryuningsih12@gmail.com
}

\section{Info Artikel}

Diterima:

8 Februari 2018

Disetujui:

20 Januari 2019

Dipublikasikan:

30 Juni 2019

\begin{abstract}
Abstrak:
Penelitian bertujuan untuk mengembangkan media pembelajaran fisika menggunakan software prezi berbasis scientific materi tata surya kelas VIII SMP. Penelitian termasuk penelitian dan pengembangan dengan model ADDIE. Subjek uji coba penelitian ini ahli media dan siswa kelas VIII A SMP Negeri 11 Muaro Jambi. Intrumen penelitian yang digunakan adalah angket studi pendahuluan, angket validasi materi dan media serta angket persepsi siswa. Teknik analisis data hasil persepsi siswa dilakukan secara statistik deskriptif. Spesifikasi produk yaitu software berbentuk prezi menggunakan format exe. Hasil validasi ahli menyatakan desain yang digunakan sesuai judul materi dan tujuan pembelajaran sehingga dinyatakan valid. Hasil uji persepsi siswa 68,12 kategori sangat baik dan reabilitas 0,8281 kategori sangat tinggi. Berdasarkan hasil diperoleh bahwa media prezi berbasis scientific materi tata surya layak digunakan sebagai bahan ajar.
\end{abstract}

Kata kunci: Media Pembelajaran, Scientific, Prezi

\begin{abstract}
:
The research aims to develop physics learning media using scientificbased prezi software for VIII SMP grade solar system material. Research includes research and development with the ADDIE model. The subjects of this research trial were media experts and class VIII A students at SMP Negeri 11 Muaro Jambi. The research instruments used were preliminary study questionnaires, material and media validation questionnaires and student perception questionnaires. The data analysis technique of students' perceptions was carried out using descriptive statistics. Product specifications namely prezi software using exe format. The results of the validation of the expert stated that the design used was in accordance with the subject matter and learning objectives so that it was declared valid. The perception test results of 68.12 students in the excellent category and reliability 0.8281 in the very high category. Based on the results obtained that the scientific media prezi based on solar system material is suitable for use as teaching material.
\end{abstract}

Keyword : Learning Media, Scientific, Prezi 
Pendahuluan

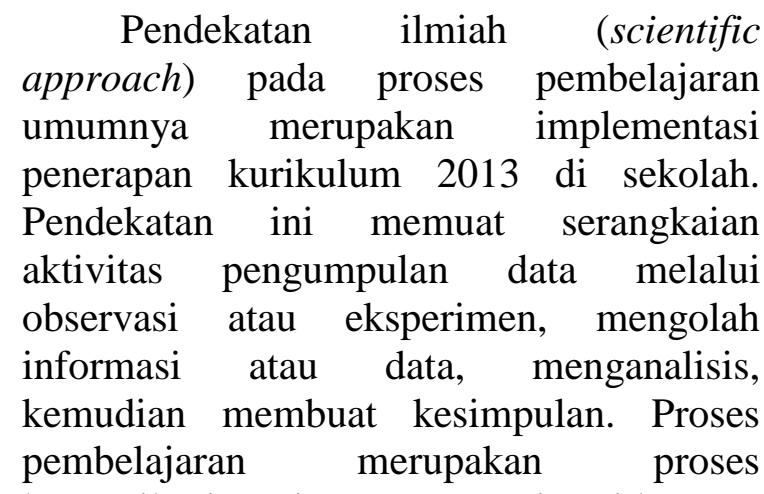

komunikasi, yaitu penyampaian ide atau informasi dari guru ke siswa. Hal ini guru sebagai pengirim informasi, sedangkan perantara atau sarana penyampaian informasi dari guru kesiswa disebut dengan media pembelajaran. Media dalam proses belajar cenderung diartikan sebagai alat-alat grafis, fotografis, atau elektronis untuk menangkap, memproses, dan menyusun kembali informasi visual atau verbal.

Berdasarkan hasil wawancara penulis dengan guru IPA di SMP Negeri 11 Muaro Jambi mengungkapkan bahwa siswa sering mengalami kesulitan dalam menerima materi. Keterbatasan media pembelajaran menjadi salah satu faktor yang menyebabkan pembelajaran fisika kurang menarik. Oleh karena itu, diperlukan suatu media alternatif yang membuat materi dalam mata pelajaran fisika yang bersifat abstrak menjadi lebih konkrit sehingga siswa dapat memahami materi pembelajaran tersebut. Berdasarkan hasil observasi penulis dengan siswa dibutuhkannya media pembelajaran pada materi Tata Surya, didapatkan hasil bahwa rata-rata siswa menginginkan adanya media pembelajaran yang menarik pada proses pembelajaran. Media ini dibutuhkan karena pada materi Tata Surya banyak hal-hal yang tidak dapat dilihat secara nyata. Oleh karena itu, diperlukan suatu media yang dapat digunakan untuk mempermudah penyampaian materi tentang Tata Surya. Pokok bahasan pada Tata Surya ini sangat erat hubungannya dengan kehidupan seharihari.
Seiring dengan pesatnya perkembangan ilmu pengetahuan dan teknologi, kini selain microsoft powerpoint banyak bermunculan program baru. Salah satunya adalah software prezi, penggunaan software prezi sebagai salah satu media pembelajaran inovatif berbasis teknologi informasi dan komunikasi. Pembelajaran menggunakan software prezi ini merupakan inovasi baru dalam pembelajaran. Dimana software prezi menjadi lebih menarik dan memberikan suasana berbeda yang dapat mengubah persepsi siswa mengenai pembelajaran Fisika. Pembelajaran fisika dengan memanfaatkan media pembelajaran prezi akan menggeser pembelajaran yang monoton menjadi pembelajaran yang variatif.

Media merupakan salah satu komponen komunikasi, yaitu sebagai pembawa pesan dari komunikator menuju komunikasi (Criticos dalam Daryanto, 2013). Berdasarkan definisi di atas, dapat dikatakan bahwa proses pembelajaran merupakan proses komunikasi. Arsyad (2016) mengemukakan bahwa media berasal dari bahasa latin medius yang secara harfiah berarti 'tengah', 'perantara' atau 'pengantar'. Dalam bahasa Arab, media adalah perantara atau pengantar pesan dari pengirim kepada penerima pesan. Gerlach \& Ely dalam Arsyad (2016) mengatakan bahwa media apabila dipahami secara garis besar adalah manusia, materi, atau kejadian yang membangun kondisi yang membuat siswa mampu memperoleh pengetahuan, keterampilan, atau sikap. Jadi media pembelajaran adalah media komunikasi yang dapat digunakan untuk menyalurkan pesan (bahan pembelajaran), sehingga dapat menimbulkan perhatian, minat, pikiran, dan perasaan siswa dalam kegiatan belajar untuk mencapai tujuan belajar

Salah satu media pembelajaran adalah media prezi. Prezi adalah sebuah perangkat lunak untuk presentasi berbasis internet atau Software as a Service (SaaS), yang dapat digunakan sebagai alat untuk mengeksplorasi dan berbagi ide di atas kanvas virtual. Menurut Rusyfian (2016) prezi menjadi unggul karena 
program ini menggunakan Zooming User Interface (ZUI) yang memungkinkan pengguna prezi untuk memperbesar dan memperkecil tampilan media presentasi. Keunggulan lainnya pada softwere prezi terdapat pada tampilan tema yang bervariasi, tidak perlu berpindah dari satu slide ke slide lainnya dan pilihan tema lebih keren yang dapat diunduh secara online. Daryanti dalam rodhi (2014) prezi dapat menggeser paradigma pembelajaran yang semula berpusat pada guru menjadi berpusat pada siswa dan guru hanya sebagai fasilitator sehingga siswa menjadi aktif belajar, tidak lagi mengandalkan guru sebagai narasumber tunggal. Dan diperkuat oleh penelitian terdahulu yang menyatakan prezi yang dapat memperbesar dan menonjolkan bagian tertentu yang sedang dibahas dan dibicarakan menjadi fokus perhatian siswa tertuju pada aspek yang ditonjolkan, namun dengan melihat aspek lain yang tetap tercantum dalam prezi. Dengan demikian, prezi dapat memudahkan siswa menangkap garis besar pembelajaran dan detailnya secara bersamaan.

Berdasarkan penelitian yang dilakukan Tanjung (2014) diketahui bahwa hasil persepsi siswa terhadap software prezi memiliki kelayakan media sangat baik. Hal ini menunjukkan bahwa media pembelajaran yang telah dikembangkan dapat digunakan sebagai media alternatif dalam pembelajaran. Oleh sebab itu software prezi perlu dikembangkan pada materi lain. Penelitian ini bertujuan untuk menghasilkan media pembelajaran fisika dengan menggunakan prezi pada materi tata surya dan untuk mengetahui persepsi siswa terhadap pengembangan media pembelajaran tersebut. Adapun manfaat dari pengembangan yaitu sebagai media ajar fisika pada pokok bahasan tata surya dan memotifasi siswa sehingga mampu meningkatkan kualitas belajar jadi lebih baik.

\section{Metode Penelitian}

Jenis Penelitian

Jenis penelitian ini adalah penelitian

dan pengembangan (Research and Development). Model pengembangan yang digunakan adalah model ADDIE yaitu singkatan dari analyze (analisis), design (desain), development (pengembangan), implementation (implementasi), dan evaluate (evaluasi) (Branch ,2009). Waktu dan Tempat
Penelitian Penelitian dilaksanakan di SMPN 11 Muaro Jambi pada tanggal 16 Agustus 2017.

Subjek Penelitian

Subjek Penelitian terdiri dari siswa kelas VIII A dan VIII B di SMAN 11 Muaro Jambi. Penelitian di kelas VIII A yaitu untuk melihat persepsi siswa terhadap prezi, sedangkan di kelas VIII B yaitu untuk reliabilitas angket.

Prosedur Pengembangan

Prosedur pengembangan bahan ajar berupa media prezi dengan pendekatan scientific pada materi tata surya ini hanya dibatasi pada tahap development (pengembangan).

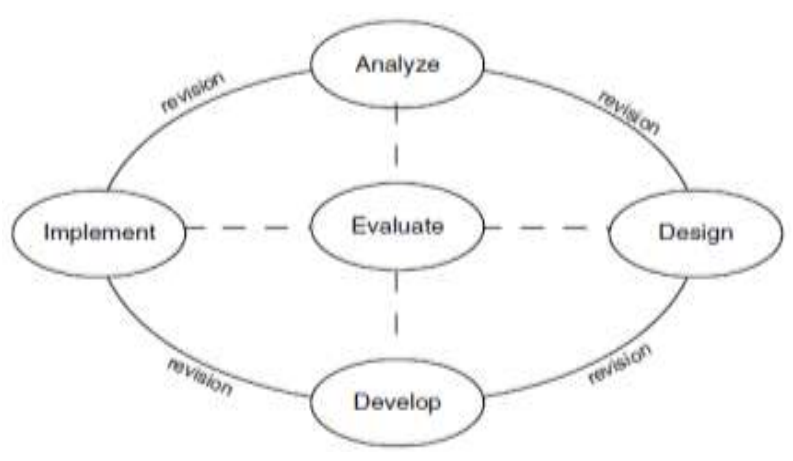

Gambar 1. Tahap Pengembangan Model ADDIE

(Sumber: Branch 2009)

\section{Analyze (Analisis)}

Tujuan dilakukannya analisis adalah mengidentifikasi permasalahan yang ada. Langkah yang dilakukan adalah memvalidasi permasalahan, menemukan tujuan, menganalisis siswa, mengecek sumber daya yang tersedia, menemukan sistem yang berpotensi dan menyusun rencana kerja.

a. Memvalidasi permasalahan

Menvalidasi permasalahan disini ialah menghasilkan sebuah pernyataan yang dapat digunakan sebagai prioritas tindakan terhadap permasalahan yang sedang dihadapi.

b. Menemukan tujuan

Tujuan dari menemukan tujuan pembelajaran adalah untuk menghasilkan tujuan yang merespon permasalahan yang disebabkan oleh kurangnya pengetahuan dan keterampilan. Proses tahapan ini akan 
diambil dengan menganalis kurikulum

13.

c. Menganalisis siswa

Tujuan analisis Siswa adalah untuk mengetahui kemampuan awal, pengalaman, hal yang disukai, dan motivasi pembelajaran mahasiswa dalam proses pembelajaran. Untuk mengetahui hal tersebut digunakan wawancara tidak terstruktur kepada siswa. Selain itu juga dilakukan wawancara kepada guru mata pelajaran.

d. Mengidentifikasi sumber yang tersedia Dalam hal ini terdapat dua jenis sumber daya yang harus dianalisis, yaitu sumber fasilitas instruksional, dan sumber daya manusia yang mempengaruhi desain, pengembangan, dan penerapan dalam pembelajaran. Analisis ini bertujuan untuk mengidentifikasi sumber daya yang akan dibutuhkan dalam pengembangan.

e. Menemukan sistem yang berpotensi

Tahapan ini bertujuan untuk menemukan potensi sistem dan merumuskan biaya pengeluaran.

f. Menyusun rencana kerja

Dalam tahap ini menyusun rencana kerja bertujuan untuk membuat dokumen yang menegaskan gambarangambaran dari semua pihak yang terlibat dalam proyek tersebut.

\section{Design (Desain)}

Tahap desain merupakan tahapan perancangan dan pembuatan produk. Langkah yang harus dilaksanakan pada tahap ini adalah mengumpulkan dan membuat produk yang telah dirancang, menyusun tujuan pengembangan, menyusun strategi pengujian, dan menghitung estimasi biaya.

a. Pengumpulan dan pembuatan produk

Untuk menghasilkan sebuah bahan ajar, hal paling mendasar yang harus dilakukan adalah pengumpulan bahan yang berupa perangkat pembelajaran berupa silabus (terlampir) dan pembuatan rancangan. Rancangan prezi dengan pendekatan saintifik mencakup beberapa aspek, yaitu:

1) Rancangan tampilan prezi

2) Rancangan isi bahan ajar

b. Menyusun tampilan objek
Berdasarkan hasil analisis yang didapat maka terlihatlah gambaran produk yang akan disusun. Dengan adanya gambaran tersebut langkah berikutnya adalah menyusun tampilan objek yang akan dibuat.

c. Menyusun strategi perencanaan Setelah menyusun rancangan tampilan objek maka strategi pengujian produk harus di rencanakan. Strategi pengujian yang dirancang adalah uji coba kelompok besar.

d. Menghitung estimasi biaya

Pada langkah ini peneliti menghitung biaya yang dikeluarkan baik pada semua tahap ADDIE juga biaya pembuatan produk.

\section{Development (Pengembangan)}

Development dalam model ADDIE berisi kegiatan realisasi rancangan produk atau pembuatan produk yang sebelumnya telah disusun pada tahap desain. Pengembangan adalah proses mewujudkan rancangan atau blue-print menjadi kenyataan. Produk yang dihasilkan berupa slide Prezi pada pokok bahasan Tata Surya. Pada bagian ini pengembangan yang dilakukan, meliputi:

a. Mengumpulkan konsep materi dari berbagai sumber referensi.

b. Storyboard yang dibuat dikembangkan menjadi produk.

c. Validasi tim ahli

Angket yang digunakan adalah angket berstruktur. Pada tahap ini, angket berstruktur akan diberikan kepada tim ahli materi dan media yang berisi pertanyaan-pertanyaan yang berkenaan dengan kelayakan media pembelajaran menggunakan software prezi. Pada tahap ini tim ahli akan memberikan saran masukan terhadap desain media dan isi materi dari kelayakan media tersebut melalui pertanyaan utama. Selanjutnya tim ahli akan memilih pilihan jawaban ya atau tidak dalam sub pertanyaan

d. Revisi Produk.

Setelah melalui tahap validasi dari tim ahli, maka akan mendapatkan hasil komentar, kritik dan saran serta masukan-masukan untuk perbaikan media pembelajaran fisika dengan 
mengurangi kelemahan-kelemahan dari pengembangan media pembelajaran fisika. Kemudian komentar, kritik dan saran serta masukan-masukan tersebut berupa data kualitatif yang akan digunakan untuk merevisi dan memperbaiki kelayakan media pembelajaran menggunakan software prezi.

Jenis Data

Jenis data yang digunakan pada penelitian pengembangan ini bersifat kualitatif dan kuantitatif. Data kualitatif yang diambil adalah saran dari tim validasi ahli, sedangkan data kuantitatif yang diambil adalah angket persepsi siswa. Data yang diperoleh dari hasil pengembangan produk ini digunakan sebagai dasar dalam menetapkan kelayakan media prezi.

Instrumen Pengumpulan Data

Adapun instrumen pengumpulan data yang digunakan antara lain.

1. Studi pendahuluan

Adapun instrumen yang digunakan dalam studi pendahuluan adalah intrumen wawancara kepada guru, instrumen wawancara kepada siswa, instrumen angket kebutuhan guru dan instrumen kebutuhan siswa. Hasil data telaah dokumen di analisis pada saat observasi awal.

2. Angket Validasi Ahli Media

Angket validasi media ini diberikan kepada 2 dosen sebagai ahli media. Manfaat dari instrumen angket media ini adalah untuk mengetahui nilai kevalidan media yang dikembangkan.

3. Angket Validasi Ahli Materi

Validasi materi ini diberikan kepada 1 dosen sebagai ahli materi. Manfaat dari instrumen ini adalah untuk mengetahui nilai kevalidan media yang dikembangkan.

4. Angket Persepsi siswa

Angket persepsi siswa ini diberikan kepada siswa pada akhir penelitian. Instrumen ini digunakan sebagai acuan menilai kelayakan desain media pembelajaran yang dikembangkan pada aspek ketepatan materi dan isi, motivasi, desain software, format dan sound.
Analisis Instrumen Penelitian

1. Analisis validitas

Validitas berkenaan dengan ketetapan alat penilaian terhadap konsep yang dinilai sehingga betul-betul menilai apa yang seharusnya dinilai. Dalam hal ini dilakukan validitas logis.

2. Analisis reliabilitas

Reliabilitas menunjuk pada satu pengertian bahwa sesuatu instrumen cukup dapat dipercaya untuk digunakan sebagai alat pengumpul data karena instrumen tersebut sudah baik. Dalam penelitian ini untuk mengukur reliabilitas ditentukan dengan rumus Cronbach Alpha sebagai berikut (Arikunto, 2013).

$$
r_{11}=\left(\frac{n}{n-1}\right)\left(1-\frac{\Sigma \sigma_{i}^{2}}{\sigma_{t}^{2}}\right)
$$

Dengan:

$$
\sigma_{t}^{2}=\frac{\Sigma X^{2}-\frac{(\Sigma X)^{2}}{N}}{N}
$$

Keterangan:

$r_{11} \quad=$ indeks korelasi (harga reliabilitas)

$n=$ banyaknya butir soal

$\Sigma \sigma_{i}^{2} \quad=$ jumlah varians butir.

$\sigma_{t}^{2} \quad=$ varians total.

$N \quad=$ banyak peserta yang mengisi angket

$X \quad=$ skor yang diberikan

Teknik Analisis Data

Teknik analisis data dalam penelitian kuantitatif yang berupa skor persepsi siswa dilakukan secara statistik deskriptif dan disajikan dalam tabel. Langkah-langkah menganalisis data kuantitatif tersebut adalah sebagai berikut:

a. Mengkuantitatifkan hasil checking dengan memberi skor sesuai dengan bobot yang telah ditentukan sebelumnya.

Tabel 1. Interval Skala Likert

\begin{tabular}{cc}
\hline Respons & Bobot Skor \\
\hline Sangat Baik & 4 \\
Baik & 3 \\
Tidak Baik & 2 \\
Sangat Tidak Baik & 1 \\
\hline (Sumber: Direktorat Pembinaan SMA, 2010)
\end{tabular}

b. Menentukan skor rata-rata indikator yang diberikan berdasarkan penilaian dari 
validasi ahli media, validasi ahli materi, dan persepsi siswa.

$$
\bar{X}=\frac{\sum X}{n}
$$

Keterangan:

$$
\begin{aligned}
\bar{X} & =\text { Mean } \\
\sum X & =\text { Jumlah skor jawaban } \\
& \text { responden } \\
\mathrm{N} & =\text { jumlah responden }
\end{aligned}
$$

c. Mengidentifikasi kecenderungan ubahan setiap sub variabel digunakan rata-rata ideal (Xi) dan standar deviasi ideal (SDi), dapat dihitung dengan acuan norma yaitu:

Xideal $=\frac{1}{2}$ (skor tertingi + skor terendah)

$$
\text { SDideal }=\frac{1}{6} \quad \text { skor tertinggi }- \text { skor }
$$
terendah)

d. Kemudian setiap sub variabel dikategorikan menjadi empat kategori dan diubah menjadi data kualitatif sebagai berikut :

Tabel 2. Rentang Skor dan Kriteria Kualitatif

\begin{tabular}{cc}
\hline Rentang Skor & Kriteria \\
\hline$X i+1,5 S D i \leq \bar{X} \leq X i+3,0 S D i$ & Sangat \\
$X i+0 S D i \leq \bar{X}<X i+1,5 S D i$ & Baik \\
$X i-1,5 S D i \leq \bar{X}<X i+0 S D i$ & Tidak Baik \\
$X i-3 S D i \leq \bar{X}<X i-1,5 S D i$ & Sangat \\
tidak Baik \\
\hline \multicolumn{2}{c}{ (Sumber: Direktorat Pembinaan SMA, 2010) }
\end{tabular}

\section{Hasil dan Pembahasan}

Prezi didesain dan dikembangkan berdasarkan hasil yang diperoleh dari tahapan observasi awal sampai pada tahapan desain. Untuk menyesuaikan apa yang dibutuhkan siswa dengan apa yang telah dikembangkan, maka dilakukan validasi sebanyak dua kali untuk media dan satu kali untuk materi. Validasi dilakukan oleh 3 orang dosen Pendidikan Fisika Universitas Jambi. Validator menilai kelayakan media ini dengan memberikan saran dan komentar pada angket penilaian media dan materi yang telah disediakan. Validasi dilakukan sampai validator menyatakan bahwa media prezi telah layak digunakan tanpa revisi.

1. Validasi Media

Pada validasi materi tahap I, berdasarkan angket yang diberikan, validator menyarankan:

1. Huruf yang digunakan pada media diganti dengan font yang bervariasi

2. Video setiap sub bab harus ada

3. Latihan soal harus interaktif dan jawabab dari soal harus dimasukkan dalam slide

Setelah seluruh saran dari validator diperbaiki, maka pada validasi tahap kedua semua validator menyatakan media prezi telah layak dan dapat digunakan.

\section{Validasi Materi}

Pada validasi materi tidak ada revisi dari validator dan materi yang dimuat dalam media pembelajaran dinyatakan layak dan dapat digunakan.

Setelah selesai divalidasi oleh dosen, tahap selanjutnya adalah melakukan uji coba pada siswa kelas VIII A dan VIII B SMPN Muaro Jambi. Hasil uji coba pada siswa kelas VIII B digunakan untuk menentukan reliabilitas angket, sedangkan hasil uji coba siswa kelas VIII A digunakan untuk menentukan persepsi siswa terhadap media prezi yang dikembangkan. Uji reliabilitas dilakukan dengan menggunakan program SPSS dengan mengacu pada persamaan Alfa Cronbach, sehingga diperoleh nilai reliabilitas angket sebesar $\mathrm{r}_{11}=0.8281$ dengan kategori reliabilitas sangat tinggi. Dari perhitungan tersebut, dapat disimpulkan bahwa angket dapat dipercaya dan dapat digunakan untuk mengambil data terhadap kelayakan media prezi yang telah dikembangkan.

Setelah didapat nilai reliabilitas angket yang digunakan, kemudian dilakukan uji coba untuk melihat kelayakan media prezi. Uji coba dilakukan pada siswa kelas VIII A, di mana data yang diambil adalah persepsi siswa terhadap media prezi yang telah dikembangkan. Angket yang digunakan terdiri dari empat indikator penilaian yaitu ketepatan materi dan isi, motivasi, desain software prezi, format dan sound. Empat indikator ini terdiri dari 20 penyataan. 
Berdasarkan angket persepsi siswa, didapatkan hasil persepsi siswa terhadap pengembangan media prezi sebagai berikut:

Tabel 3. Hasil persepsi siswa terhadap pengembangan media prezi

\begin{tabular}{|c|c|c|}
\hline Indikator & Skor & Ket. \\
\hline $\begin{array}{c}\text { Ketepatan materi } \\
\text { dan isi }\end{array}$ & 26,83 & $\begin{array}{l}\text { Sangat } \\
\text { Baik }\end{array}$ \\
\hline Motivasi & 7,20 & $\begin{array}{c}\text { Sangat } \\
\text { Baik }\end{array}$ \\
\hline Desain Software & 9.91 & $\begin{array}{l}\text { Sangat } \\
\text { Baik }\end{array}$ \\
\hline $\begin{array}{l}\text { Format dan } \\
\text { sound }\end{array}$ & 24,16 & $\begin{array}{c}\text { Sangat } \\
\text { Baik }\end{array}$ \\
\hline
\end{tabular}

Berdasarkan tabel 3 dapat disimpulkan bahwa media prezi yang telah dikembangkan dikategorikan memiliki kelayakan yang sangat baik. Hasil ini dihitung berdasarkan rumus yang di ambil dari Juknis Penilaian Afektif dengan menggunakan skala 4.

Hal tersebut dapat dilihat dari skor yang didapatkan untuk indikator ketepatan materi dan isi dengan 8 pernyataan sebesar 26,83 dalam kategori sangat baik, indikator Motivasi dengan 2 pernyataan sebesar 7,20 dalam kategori sangat baik, indikator desain software dengan 3 pernyataan sebesar 9.91 dalam kategori sangat baik, serta indikator format dan sound dengan 7 pernyataan sebesar 24,16 dalam kategori sangat baik, dan untuk hasil persepsi siswa secara keseluruhan dengan 20 pernyataan sebesar 68,12 dalam kategori sangat baik.

\section{Spesifikasi}

1. Prezi menggunakan program Zooming User Inteerface (ZUI) yang memiliki format exe. Dalam pembuatannya terdapat beberapa software yang dibutuhkan dalam proses pengembangan media prezi, antara lain yaitu:

a. Adobe Flash Player, yang berfungsi untuk membuat animasi digital dan web sites yang interaktif

b. Adobe Photoshop, yang berfungsi untuk melakukan crop gambar, mengubah ukuran gambar, menyesuaikan dan membenarkan warna gambar

c. Camtasia Studio, yang berfungsi untuk mengedit video, seperti memotong video, menambahkan audio ke video, dan lain sebagainya.

2. Desain yang dibuat dengan konsistensi warna yang menarik agar tidak terkesan terlalu berwarna dengan tampilan $3 D$.

3. Adapun materi pada media prezi adalah anggota tata surya, matahari sebagai bintang, asal-usul tata surya, dan bumi sebagai planet.

4. Kegiatan pembelajaran yang sesuai dengan langkah-langkah pendekatan scientific.

Keunggulan

Keunggulan yang terdapat pada prezi yaitu:

1. Media prezi mudah dibaca karena menggunakan metode Zooming User Interface yang mana dapat memperbesar dan menonjolkan bagian tertentu yang sedang dibahas.

2. Siswa dapat memfokuskan dirinya pada materi yang akan disampaikan oleh guru melalui tampilan media yang menarik karena adanya video dan gambar.

3. Media prezi berbasis pendekatan scientific dapat langsung digunakan tanpa harus memiliki aplikasinya sehingga memudahkan dalam menggunakannya.

4. Penggunaannya juga sangat mudah, karena toolbar yang tidak banyak

Kelemahan

Kelemahan yang terdapat pada prezi yaitu:

1. Sulit memasukkan simbol matimatika

2. Jika digunakan dalam jangka waktu yang lama fitur yang lebih lengkap dikenakan biaya

3. Proses instalasi membutuhkan koneksi internet.

Kajian Produk Akhir

Adapun kajian produk akhir dari media prezi yang telah dikembangkan sebagai berikut:

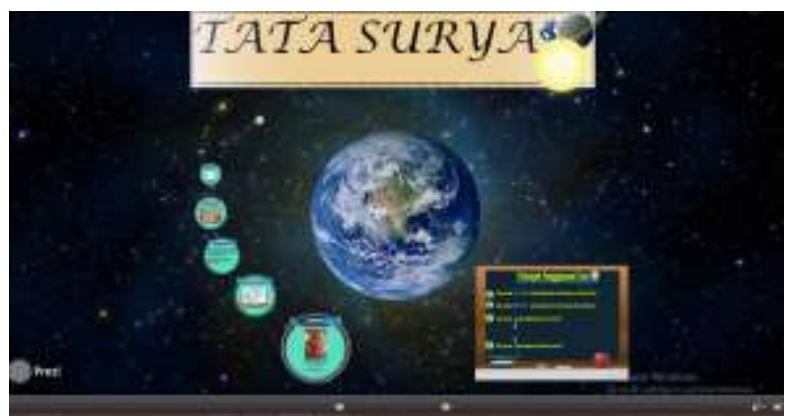

Gambar 2. Cover 


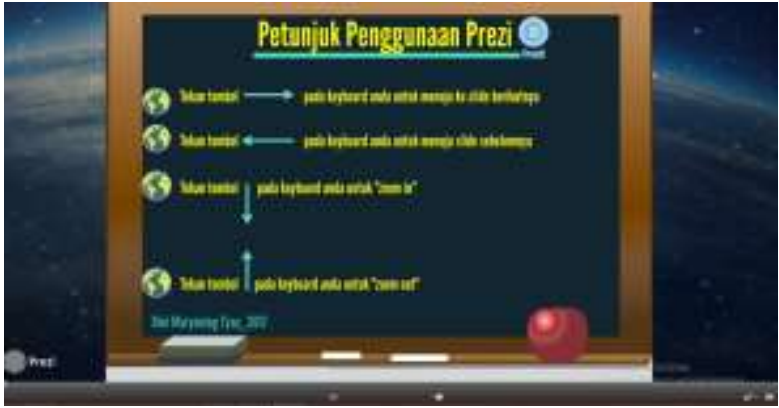

Gambar 3. Petunjuk penggunaan media

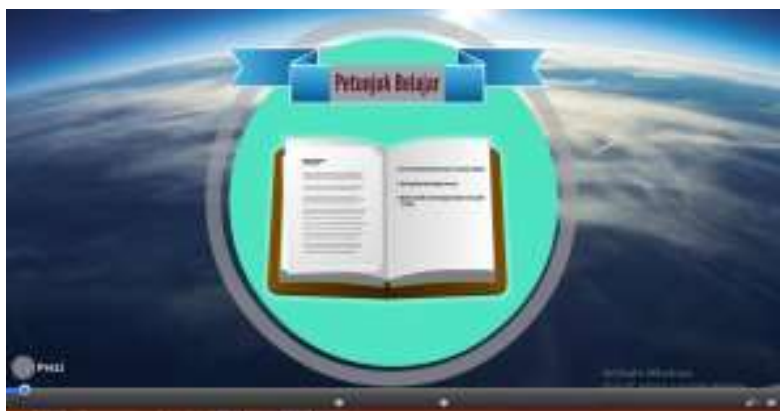

Gambar 4. Petunjuk belajar

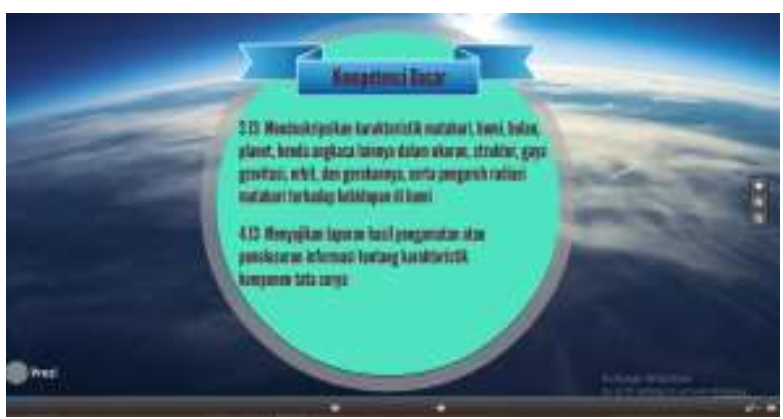

Gambar 5. Kompetensi dasar

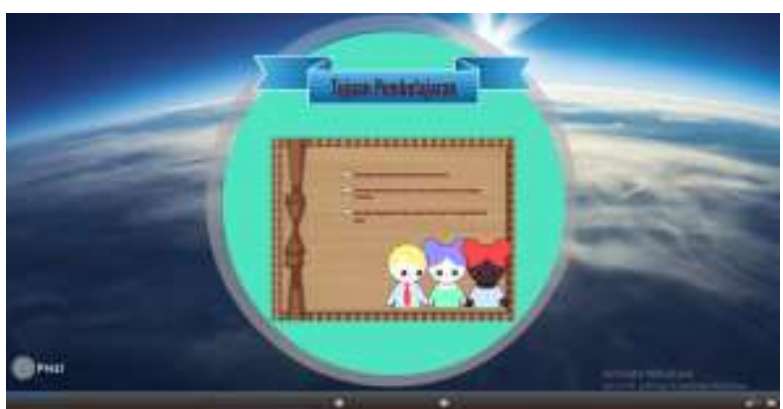

Gambar 6. Tujuan pembelajaran

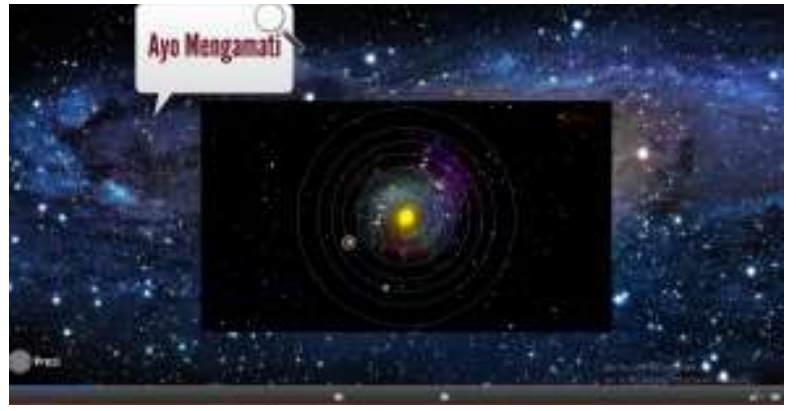

Gambar 7. Pendekatan scientific (mengamati)

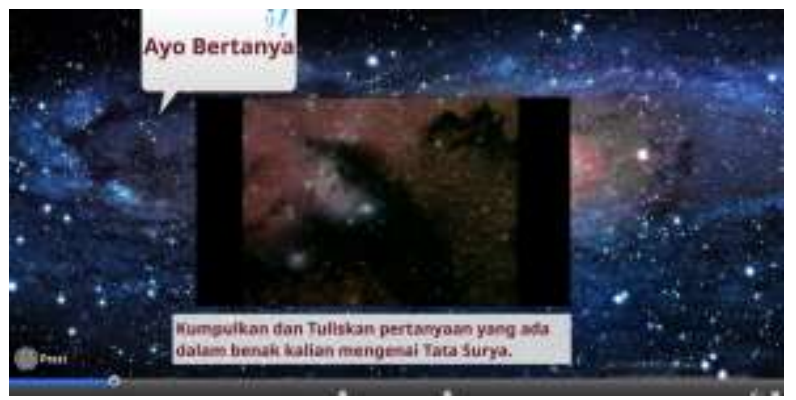

Gambar 8. Pendekatan scientific (menanya)

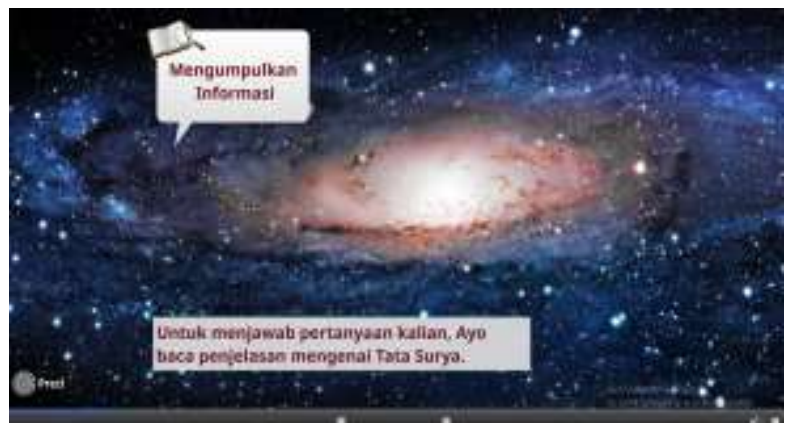

Gambar 9. Pendekatan scientific (mengumpulkan informasi)

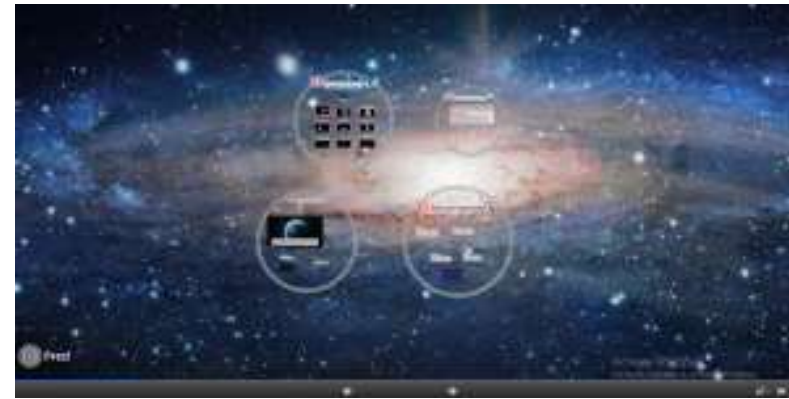

Gambar 10. Penjelasan materi 


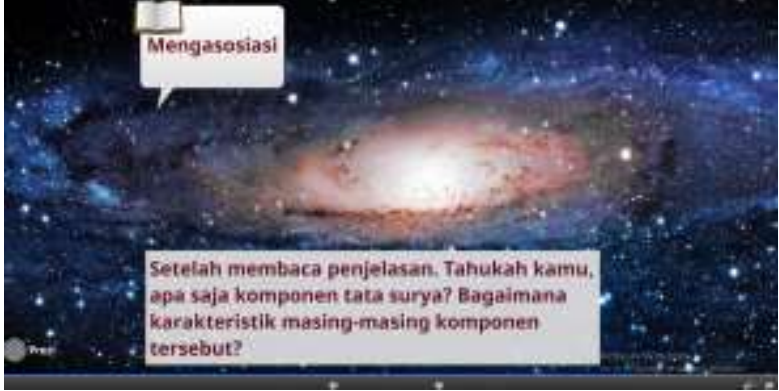

Gambar 11. Pendekatan scientific (mengasosiasi)

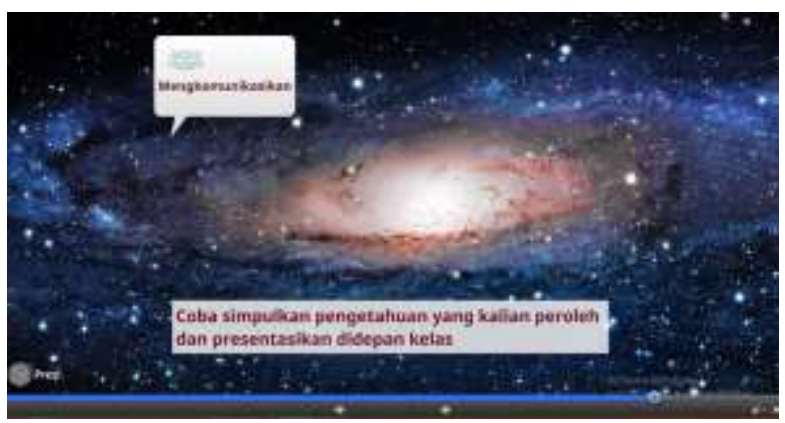

Gambar 12. Pendekatan scientific (mengumpulkan informasi)

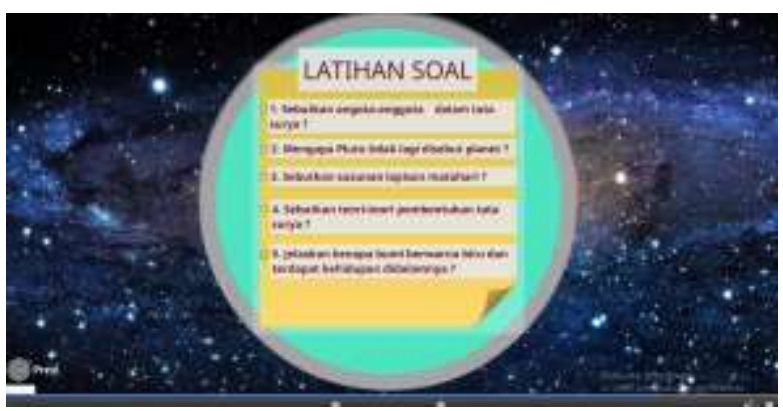

Gambar 13. Tampilan latihan soal

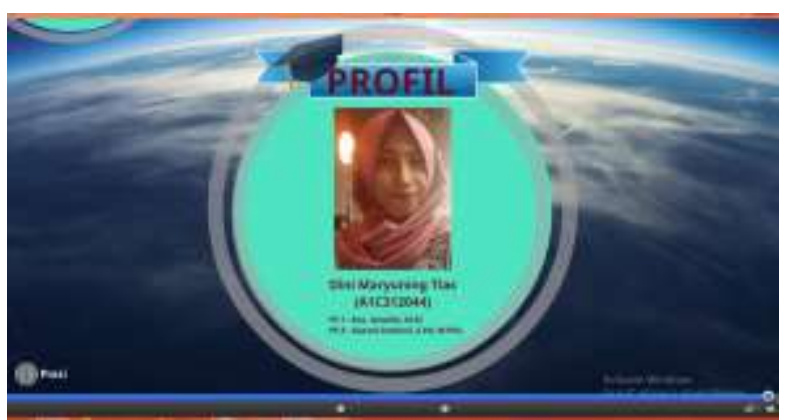

Gambar 14. Profil penulis

\section{Simpulan dan Saran}

Simpulan

Berdasarkan hasil pengembangan dan uji coba lapangan yang telah dilakukan maka dapat ditarik kesimpulan bahwa media pembelajaran menggunakan Software Prezi berbasis scientific ini dikembangkan dengan prosedur ADDIE yang tidak komplit yakni hanya sampai pada tahap development (pengembangan). Produk yang dihasilkan penelitian ini adalah media prezi berbasis pendekatan scientific. Spesifikasi produk yaitu prezi menggunakan program en:Zooming User Interface yang memiliki format exe. Adapum materi pada prezi adalah tata surya. Kegiatan pembelajaran yang sesuai dengan langkahlangkah pendekatan scientific. Adapun keunggulan dari prezi yaitu mudah dibaca karena menggunakan metode Zooming User Interface yang mana dapat mempebesar dan menonjolkan bagian tertentu yang sedang dibahas. Sedangkan kelemahan dari prezi adalah sulit untuk memasukkan simbol matimatika

Media pembelajaran menggunakan software prezi berbasis scientific ini untuk pembelajaran fisika SMP kelas VIII layak digunakan untuk mendukung pembelajaran siswa. Hasil validasi ahli menyatakan bahwa desain berupa background, gambar, dan video yang digunakan sudah sesuai dengan tujuan pembelajaran sehingga dapat dinyatakan valid dan layak digunakan. Serta telah dilakukan pengambilan data persepsi siswa kepada siswa kelas VIII SMP Negeri 11 Muaro Jambi. Hasil data persepsi siswa sebesar 68,12 yang termasuk kategori sangat baik dan nilai reliabilitas angket sebesar 0,8281 dengan kategori reliabilitas sangat tinggi.

Saran

Saran yang dapat diberikan oleh peneliti bagi peneliti berikutnya adalah:

1. Diharapkan penelitian selanjutnya yang akan mengembangkan media prezi disarankan untuk menguji pengaruh penggunaan software prezi pada pokok bahasan tata surya kelas VIII SMP ini terhadap hasil belajar siswa

2. Perlu diupayakan kegiatan penelitian lebih lanjut untuk mengetahui tingkat keefektifannya dalam pembelajaran fisika

3. Diharapkan pengembangan dan penelitian selanjutnya terhadap software prezi berbasis pendekatan scientific agar menambahkan animasi pada sub materi 1 dan 4, perbaiki video pada tahap mengamati dan bertanya 


\section{Daftar Pustaka}

Abidin, Yunus. (2014). Desain Sistem Pembelajaran Dalam Konteks Kurikulum 2013. Bandung : PT Refika Aditama.

Arikunto, Suharsimi. (2013). Prosedur Penelitian : Suatu Pendekatan Praktik. Jakarta : Rineka Cipta

Arsyad, Azhar. (2016). Media Pembelajaran. Jakarta : PT Rajagrafindo Persada.

Branch, Robert Maribe. (2009). Instructional Design-Tha ADDIE Aproach. Amerika : Department of Educational Psychology and Instructional Technology University of Georgia

Daryanto. (2013). Media Pembelajaran. Yogyakarta : Gava Media.

Daryanto, (2014). Pendekatan Pembelajaran Saintifik kurikulum 2013. Yogyakarta: Gava Media.
Direktorat Pembinaan SMA. (2010). Juknis Penyusunan Perangkat Penilaian Afektif di SMA. Jakarta: Kementerian Pendidikan Nasional

Kemundikbud No 81A. (2013). Iplementasi Kurikulum. Republik Indonesia : Peraturan Menteri Pendidikan dan Kebudayaan Republik Indonesia.

Rodhi, Wasis. (2014). Pengembangan Media Pembelajaran Berbasis Prezi Untuk Meningkatkan Keterampilan Berpikir Kritis Pada Materi Kalor. Jurnal Inovasi Pendidikan Fisika (JIPF) : 137142

Rusyfian, Zurrahma. (2016). Prezi Solusi Presentasi Masa Kini. Bandung : Informatika. 